\title{
Identification of rice blast disease-suppressing bacterial strains from the rhizosphere of rice grown in Pakistan
}

\author{
Zakira Naureen $^{1,2}$, Adam H. Price ${ }^{3}$, Fauzia Y. Hafeez ${ }^{2,4}$, \\ and Michael R. Roberts ${ }^{1}$. \\ ${ }^{1}$ Lancaster Environment Centre, Lancaster University, Lancaster, LA1 4YQ, UK. \\ ${ }^{2}$ Plant Microbiology Division, National Institute for Biotechnology and Genetic Engineering \\ (NIBGE), P.O. Box 577, Jhang Road, Faisalabad 3800-Pakistan. \\ ${ }^{3}$ Institute of Biological and Environmental Sciences, University of Aberdeen, AB24 3UU, UK.
}

\author{
Corresponding Author: \\ Dr. Michael R. Roberts \\ E-mail: m.r.roberts@lancaster.ac.uk
}

Tel: +441524510210

Fax: +44 1524593192

${ }^{4}$ Present Address: Department of Biosciences, COMSATS Institute of Information Technology, Chak Shahzad Campus, Park Road, Islamabad, Pakistan. 


\section{Abstract}

Sixteen bacterial strains isolated from the roots and rhizosphere of rice plants growing in saline and non-saline soils from the Shorkot area of Pakistan were tested for their ability to promote plant growth and reduce the incidence of rice blast disease. When applied to the soil, many of the isolated rhizobacterial strains increased seedling growth and/or suppressed rice blast disease in greenhouse-grown plants of the cultivars Super Basmati and Azucena, but each cultivar responded to different subsets of the bacteria. In the cv Super Basmati, increased blast resistance was correlated with the production of siderophores by the rhizobacteria. Several strains inhibited the growth of the causative agent of rice blast disease, the fungal pathogen Magnaporthe grisea, in an in vitro dual culture assay. Direct bioantagonism was correlated with disease resistance in Super Basmati, but not in Azucena, and direct antagonism as a cause for the reduced disease incidence is also unlikely since no epiphytic colonisation of leaves was detected. Rhizosphere colonisation by the bacteria in plants grown in sterile sand was correlated with disease resistance in Super Basmati, but not in Azucena. As well as the differences in strains that protected each cv against blast disease, we also found that there were differences in the ability of some strains to protect plants against blast depending on soil type. Hence, there are complex interactions between rhizobacteria and rice plants with respect to biocontrol of rice blast disease, dependent upon both rice $\mathrm{cv}$ and soil type. The identity of strains that promoted high levels of disease protection, including three that performed well across all plant cultivars and growth conditions, was determined by $16 \mathrm{~S}$ rRNA gene sequencing.

\section{Key words}

Rice, rhizobacteria, siderophores, blast disease, bioantagonism, induced systemic resistance. 


\section{Introduction}

Rice is one of the most important staple foods for the increasing world population, especially in Asia. Diseases are among the most significant limiting factors that affect rice production, causing annual yield losses conservatively estimated at 5\% (Song and Goodman, 2001). More than 70 diseases caused by fungi, bacteria, viruses or nematodes have been recorded on rice (Manandhar et al., 1998), among which rice blast (Magnaporthe grisea) is the most serious constraint on high productivity (Song and Goodman, 2001). Resistant cultivars and the application of pesticides have been used for blast control. However, the useful life-span of many resistant cultivars is only a few years, due to the breakdown of the resistance in the face of high pathogenic variability of the pathogen population. The use of pesticides is costly as well as environmentally undesirable. Thus, there is a need to develop strategies providing durable resistance that are useful over a broad geographic area (Manandhar et al., 1998).

Among such new strategies, biocontrol agents appear to hold promise in blast management. Since biological control is a key component of integrated disease management, it is important to search for plant growth-promoting rhizobacteria (PGPR) active against blast and to evaluate these antagonists for application in field conditions. Many microorganisms from the rhizosphere can positively influence plant growth and plant health and are referred to as PGPR (Compant et al., 2005). These microbes can act as biocontrol agents in several ways, including niche exclusion, bioantagonism and induction of induced systemic resistance (ISR) against infection by fungal, bacterial and viral pathogens in different plant species (Compant et al., 2005). The mechanisms by which PGPR activate ISR are not yet understood, but it is clear that there is substantial variation between different microbes and plants. A range of different molecules have been identified as elicitors of ISR in different systems, including conserved effectors such as flagellar peptides and lipopolysaccharides, as well as antibiotics, cyclic lipopeptides and siderophores (Compant et al., 2005; Van Wees et al., 
2008). The ability to secrete siderophores into the environment is an important feature of many PGPR. Siderophores are iron-chelating compounds that many microbes use to acquire iron from the soil. Siderophore-producing bacteria are able to out-compete other soil microbes, providing one mechanism for their bioantagonistic properties (Duffy and Défago, 1999). In addition, siderophores have been identified as molecules able to activate ISR in several plant species, providing a second mechanism for protection of plants against disease by siderophore-producing PGPR (Leeman et al., 1996a; Audenaert et al., 2002; Meziane et al., 2005). Recently, the siderophore pseudobactin was found to be an important determinant of ISR against blast disease in rice (De Vleesschauwer et al., 2008).

We are working towards commercial development of PGPR as a method for both plant growth promotion and biocontrol. Many greenhouse studies (Kaiser et al., 1989; Montealegre et al., 2003) and field experiments (Kazempour, 2004) have been conducted to show the efficacy of PGPR in disease management, but there are still relatively few commercial applications of PGPR for this purpose. Here, we report on the selection of PGPR strains for suppression of rice blast disease, and show that complex interactions exist between the different biochemical and physiological properties of these strains and their ability to promote blast resistance in rice.

\section{Materials and methods}

\subsection{Bacterial strains and growth conditions}

Bacterial strain Z2-7 had previously been isolated from rice grown in Zanzibar (Yasmin et al., 2004) and was taken from the BIRCEN culture collection, Plant Microbiology Division,

NIBGE. All other strains were isolated from the roots or rhizosphere of the rice cv Super Basmati, cultivated in either saline or non-saline soils in the area of Shorkot, Pakistan. Bacteria were isolated either from the rhizoplane or from roots of healthy rice plants, as 
follows: root pieces from rice plants were washed with tap water, placed inside tubes containing $2 \mathrm{~mL}$ of $0.5 \% \mathrm{MgSO}_{4}$ and subjected to ultrasound at $50-55 \mathrm{KHz}$ for $5 \mathrm{~min}$ (Pumarino, 1995). The bacterial suspension obtained was diluted $10^{-3}, 10^{-5}$ and $10^{-7}$ for selection. For rhizospheric strains, $1 \mathrm{~g}$ of soil was placed in a tube containing $100 \mathrm{~mL}$ of sterile distilled water, and dilutions performed as above. For both types of samples, $0.1 \mathrm{~mL}$ of each dilution was spread on Luria Bertani (LB) agar and incubated at $28 \pm 2^{\circ} \mathrm{C}$ until colony development was observed.

\subsection{Morphological and physiological characterization}

Purified bacterial strains were studied for colony and cell morphology using light microscopy and Gram staining (Vincent, 1970). Indole acetic acid (IAA) production by these bacterial strains was estimated as described by Hameed et al., (2004) and P-solubilization was assessed on Pikovskaya's medium containing tricalcium phosphate (Pikovskaya, 1948).

\subsection{Nitrogenase activity}

Nitrogenase activity of bacterial strains was determined in semi-solid nitrogen-free malate medium (NFM; Okon et al., 1977) by using an acetylene reduction assay (ARA) (Hardy et al., 1973). Pure bacterial colonies were inoculated onto NFM medium in $10 \mathrm{~mL}$ McCartney vials and incubated at $28 \pm 2{ }^{\circ} \mathrm{C}$ for $48 \mathrm{~h}$. Acetylene (10\% v/v in air) was injected to the vials. After incubation for $16 \mathrm{~h}$ at $28 \pm 2{ }^{\circ} \mathrm{C}$, gas samples $(100 \mu \mathrm{L})$ were analyzed for acetylene reduction on a gas chromatograph (Carlo Erba-Model GC 180-series 2150) using a PorapakQ column and $\mathrm{H}_{2}$ flame ionization detector. Protein estimation was carried out to measure the specific activity of the cultures as described by Lowry et al., (1951).

\subsection{Siderophore production}


Siderophore production was detected using the universal chrome azurol ' $S$ ' (CAS) assay (Schwyn and Neilands, 1987). CAS plates were streaked with overnight grown cultures and incubated at $28 \pm 2^{\circ} \mathrm{C}$ for $72 \mathrm{~h}$ (Sharma and Johri, 2002).

\subsection{Hydrogen cyanide production}

Production of HCN was determined by modified method of Miller and Higgins (1970). Bacterial culture $(48 \mathrm{~h})$ was streaked on $\mathrm{LB}$ amended with glycine $\left(4.4 \mathrm{~g} \mathrm{~L}^{-1}\right)$ and a filter paper soaked in $0.5 \%(\mathrm{w} / \mathrm{v})$ picric acid in $1 \% \mathrm{Na}_{2} \mathrm{CO}_{3}$ placed in the upper lid of the Petri plate. After incubation at $28 \pm 2^{\circ} \mathrm{C}$, changes in colour were examined.

\subsection{Production of diffusible antibiotics}

Potato dextrose agar plates, covered with a $0.2 \mu \mathrm{m}$ cellophane membrane, were inoculated in

the centre with $100 \mu \mathrm{L}$ of a bioantagonistic bacterial suspension $\left(5 \times 10^{9} \mathrm{cfu} \mathrm{mL}^{-1}\right)$. After incubation for $72 \mathrm{~h}$ at $28 \pm 2^{\circ} \mathrm{C}$, the membrane with the grown bacterial isolate was removed, and the plate was inoculated in the middle with a $10 \mathrm{~mm}$ disk of a pure culture of M. grisae. Plates were further incubated at $28 \pm 2^{\circ} \mathrm{C}$ for $48 \mathrm{~h}$ and the growth of the pathogen (colony radius) was measured as the distance between the point of placement of fungal disk and actively growing edges of the fungus. Sterile double distilled water replaced the bacterial suspension in control plates. Each experiment was run in triplicate and was repeated at least three times. Results are expressed as mean \% inhibition of the growth of the corresponding M. grisae isolate in the absence of any bacteria. Percent inhibition was calculated using the following formula: $\%$ inhibition $=(1-[$ Fungal growth $/$ Control growth $]) \times 100$

\subsection{Production of volatile antibiotics}


To check the production of volatile antibiotics, $100 \mu \mathrm{L}$ of bacterial suspension $\left(5 \times 10^{9} \mathrm{cfu}\right.$ $\mathrm{mL}^{-1}$ ), were placed at the centre of a Petri dish containing Kings' B medium, and a $10 \mathrm{~mm}$ disk of a 4-d old pure culture of $M$. grisae was placed at the centre of another Petri dish containing PDA. Both half plates were placed face to face preventing any physical contact between the pathogen and the bacterial suspension. Plates were then sealed to isolate the atmosphere inside and to prevent loss of any volatiles formed. In control plates, bacterial suspension was replaced with sterile double-distilled water. Plates were incubated at $28 \pm 2^{\circ} \mathrm{C}$ for $48 \mathrm{~h}$ and the growth of the pathogen was measured as mentioned above and compared to controls. Experiments were run in triplicate and repeated at least three times. Results are expressed as mean \% inhibition of the growth of the corresponding $M$. grisae isolate in the absence of any bacteria. Percent inhibition was calculated as above.

\subsection{Protease and chitinase production}

Bacterial isolates were checked for production of proteases by growing them on skimmed milk agar (SKM) as described by Kazempour (2004). An ability to clear the skimmed milk suspension in the agar was taken as evidence of the secretion of proteases. To assay the production of chitinases, bacteria were grown on medium containing chitin as the sole carbon source (Montealegre et al., 2003).

\subsection{Pathogenicity of bacteria}

In order to test whether bacteria were pathogenic to rice plants, seeds were immersed in a suspension of the antagonistic bacteria $\left(5 \times 10^{9} \mathrm{cfu} \mathrm{mL}^{-1}\right)$ for $5 \mathrm{~min}$ (Raupach and Kloepper, 1998). Sterile distilled water was used as a control. Once treated, seeds were germinated in autoclaved soil. Seedlings were maintained under glasshouse conditions at $25-28^{\circ} \mathrm{C}$ with daily watering with the addition of fertilizers. Height, number of leaves, and fresh weights 
were measured after 30 d. Experiments were repeated six times. Data was analyzed using the Duncan Multiple Test to test for significant differences.

\subsection{Dual culture antagonism assays}

M. grisea isolate Ch155 was originally collected in China by Professor Shen at the Chinese National Rice Research Institute and distributed by Didier Tharreau, CIRAD, Montpellier, France. A $10 \mathrm{~mm}$ disk of a pure culture of $M$. grisea grown on potato dextrose agar (PDA) was placed at the centre of a Petri dish containing PDA. A circular inoculum, made with a 6 $\mathrm{cm}$ diameter Petri dish dipped in a suspension of bacteria $\left(5 \times 10^{9} \mathrm{cfu} \mathrm{mL}^{-1}\right)$, was placed surrounding the fungal culture. Plates were cultured for $72 \mathrm{~h}$ at $28 \pm 2{ }^{\circ} \mathrm{C}$ and growth diameter of the pathogen (distance between the point of placement of fungal disk and actively growing edges of the fungus) was measured and compared to control growth where the bacterial suspension was replaced by sterile distilled water. Each experiment considering a single bacterial isolate was run in triplicate and was repeated at least three times. Results are expressed as mean \% inhibition of the growth of the corresponding $M$. grisea isolate in the absence of any bacteria.

Percent inhibition was calculated as above.

\subsection{Disease resistance in greenhouse-grown rice plants}

PGPR inoculations. Rice seeds (cvs Super Basmati and Azucena) were sterilised and germinated on moist filter paper in sterile Petri dishes. Ten days after germination, three seedlings were transplanted to each pot $(25 \mathrm{~cm}$ diameter $)$ containing autoclaved soil. Plants were kept in the greenhouse at a temperature of $28 \pm 2^{\circ} \mathrm{C}$ during the day and $25 \pm 2^{\circ} \mathrm{C}$ at night

for $40 \mathrm{~d}$. For inoculation of plants, bacterial cultures were grown in LB broth for $24-48 \mathrm{~h}$ at $28 \pm 2^{\circ} \mathrm{C}$. Cell pellets were obtained by centrifugation at $6000 \times \mathrm{g}$ for $5 \mathrm{~min}$, washed and 
resuspended in sterile water. Soils in which seedlings were growing were inoculated with 1 $\mathrm{mL}$ of bacterial suspension $\left(10^{8}-10^{9}\right.$ cells $\left.\mathrm{mL}^{-1}\right)$ of individual strains and plants left for $7 \mathrm{~d}$ under standard conditions. Parallel experiments were performed in which plants were grown in autoclaved sand rather than soil. Plants were grown in same conditions, watered regularly with autoclaved water and were given $1 / 4$ strength Hoagland's solution for nutritional requirements.

Challenge inoculation. The blast fungus was cultured on rice flour agar $\left(20 \mathrm{~g} \mathrm{~L}^{-1}\right.$ rice flour, $2.5 \mathrm{~g} \mathrm{~L}^{-1}$ yeast extract $1.5 \%$ agar) and incubated at $25^{\circ} \mathrm{C}$ under fluorescent lights with a $12 \mathrm{~h}$ photoperiod for 2-3 weeks. Spores of the fungus were harvested by flooding the agar plate cultures with $5-7 \mathrm{~mL}$ sterile water containing $0.5 \%$ gelatine, filtered through $0.2 \mu \mathrm{m}$ nylon meshes and transferred immediately to a container containing ice to prevent spore germination. Spore concentration was adjusted to $1 \times 10^{5}$ spores $\mathrm{mL}^{-1}$.

40-d-old rice plants of all of the treatments and control were transferred to the inoculation chamber $1 \mathrm{~d}$ before the inoculation to acclimatize the new environment $\left(28 \pm 5^{\circ} \mathrm{C}\right.$ day and $25 \pm 5^{\circ} \mathrm{C}$ night temperature and relative humidity above $90 \%$ ). About $100 \mathrm{~mL}$ of the fungal spore inoculum was sprayed over the plants in the evening. Immediately after inoculation, the plants were covered with a polythene hood and black polythene sheets for 24 $\mathrm{h}$ to stimulate infection in the dark. Each experiment included five replicates per treatment and three plants per replicate.

Disease assessment. Six days after fungal inoculation, each plant was assessed individually for blast infection. Each leaf was scored for number and size of lesions. Disease incidence was evaluated according to a lesion index: small brown spots ( $\mathrm{R}$; lesion diameter $<2 \mathrm{~mm}$ ), small brown lesion encircled by a whitish zone (RS; $2 \mathrm{~mm} \leq$ lesion diameter $<5 \mathrm{~mm}$ ), small whitish lesion encircled by a brown zone (MS; $2 \mathrm{~mm} \leq$ lesion diameter $<5 \mathrm{~mm}$ ) and large lesion $(\mathrm{S} ; 5 \mathrm{~mm} \leq$ lesion diameter $)$, and disease index $=\{(1 \times \mathrm{nR}+2 \times \mathrm{nRS}+3 \times \mathrm{nMS}+$ 
$4 \times \mathrm{nS}) \div$ number of seedlings $\}$ (Someya et al., 2002). The experiment was carried out independently on three occasions using a completely randomized block design with six replications for each treatment. Mean disease index (MDI) data from each replicated experiment was analysed by two-way ANOVA with strain and cv as the two factors.

After initial disease scoring, plants were kept under normal greenhouse conditions for another period of $40 \mathrm{~d}$, and then percentage survival of the plants was calculated.

\subsection{Ephipytic and rhizospheric colonization by bacteria}

Leaf and root apex samples from 45 rice plants grown in sand inoculated with each bacterial strain were taken 7, 25 and $45 \mathrm{~d}$ after inoculation to check for ephiphytic and rhizospheric colonization of bacteria. Leaf and root extracts were made and serial dilutions of $10^{-3}, 10^{-5}$ and $10^{-7}$ were made for selection of bacteria. For both types of samples, $0.1 \mathrm{~mL}$ of each dilution was placed on Luria Bertani (LB) agar and incubated at $28 \pm 2^{\circ} \mathrm{C}$ for $48-72 \mathrm{~h}$ or until colony development was observed.

\subsection{Partial 16S rRNA amplification and sequencing}

DNA was extracted from selected bacterial isolates (DNeasy Tissue kit, QIAGEN) and used to amplify a fragment of the $16 \mathrm{~S}$ ribosomal RNA gene (Yang et al., 1985) using universal primers Y1 and Y2. The forward primer Y1 (5'-TGGCTCAGAACGAACGCTGGCGGC-3') corresponds to positions 20-43 in the Escherichia coli 16S rRNA sequence (Young et al., 1991), and the reverse primer Y2 (5'-CCCACTGCTGCCTCCCGTAGGAGT-3') corresponds to position $361-338$ of the gene. Each $50 \mu \mathrm{L}$ PCR reaction mixture contained $0.2 \mu \mathrm{L}$ of Taq DNA Polymerase (50 U $\mu \mathrm{L}^{-1}$; Promega), $5 \mu \mathrm{L}$ 10x PCR buffer, $4 \mu \mathrm{L} 2.5 \mathrm{mM}$ dNTPs, $1 \mu \mathrm{L}$ of each primer (100 ng $\left.\mu \mathrm{L}^{-1}\right)$ and $1 \mu \mathrm{L}$ template DNA $\left(12.5 \mathrm{ng} \mu \mathrm{L}^{-1}\right)$ and underwent 35 rounds of temperature cycling $\left(94^{\circ} \mathrm{C}\right.$ for $1 \mathrm{~min}, 50^{\circ} \mathrm{C}$ for $2 \mathrm{~min}$ and $72^{\circ} \mathrm{C}$ for $3 \mathrm{~min}$ ). This was 
followed by incubation at $72^{\circ} \mathrm{C}$ for $7 \mathrm{~min}$. PCR products were purified using QIAquick PCR Purification Spin kits (QIAGEN) and directly used for sequence analysis (Lancaster University Sequencing Facility). The sequences obtained were searched on BlastX (http://www.ncbi.nlm.nih.gov/BLAST/). Sequences were deposited in the EMBL gene bank database.

\section{Results}

\subsection{Isolation of bacterial strains}

A total of 16 bacterial strains isolated from the rhizosphere and roots of rice cultivated in normal and saline soils from Shorkot in Pakistan were selected for detailed investigation. Species diversity investigation amongst these, indicated that they likely belong to a range of different bacterial genera, including Enterobacter, Bacillus and Pseudomonas, as they showed morphological characteristics most closely resembling these genera (Farmer et al., 1992; Grimont and Grimont 1992; Hassan et al., 1998).

Different strains exhibited different combinations of properties for nitrogen fixation, $\mathrm{P}$ solubilization, and the production of siderophores, IAA, proteases, chitinases and HCN. Although only one strain (SPR7) showed HCN production, none were positive for $\mathrm{N}$ fixation. The data are summarized in Table 1.

\subsection{Pathogenicity and effects of bacteria on plant growth}

No signs of pathogenicity, such as lesion formation or wilting were observed in the seedlings that had been incubated with bacterial cultures. Significant differences were observed in plant growth promotion effects on both shoot fresh weights and seedling height by the bacteria in inoculated seedlings of both cultivars after one month (Table 2). 


\subsection{Disease suppression in greenhouse-grown plants}

When bacterial cultures were applied to the soil $7 \mathrm{~d}$ prior to pathogen inoculation, isolates BPS10, SPR4, WBPS1, Z2-7, SPS2, SPR5 and WBPR4 reduced the disease index to a range of $7.5 \%$ to $27.5 \%$ relative to controls in Azucena (Table 3). In Super Basmati plants, bacterial isolates WBPS1, BPS12, Z2-7, SPS2 and WBPS2 reduced the disease index to a range of $17.5 \%$ to $40 \%$ compared to control plants in the absence of PGPR (Table 3). Other isolates had smaller effects, but no strain tested failed to provide protection in at least one cv. Statistical analysis using two-way ANOVA indicated that both bacterial strain $(\mathrm{F}=309, \mathrm{P}<$ $0.0001)$ and plant $\mathrm{cv}(\mathrm{F}=1280, \mathrm{P}<0.0001)$ affect the level of disease, and that there is also a significant interaction between strain and $\mathrm{cv}(\mathrm{F}=190, \mathrm{P}<0.0001)$. This latter result suggests that the two cvs respond differently to the bacterial strains.

To investigate the source of this difference, we performed point biserial correlation analysis to examine possible relationships between the production of antibiotics, siderophores and hydrolytic enzymes, and disease resistance in the two rice cvs. The results indicate that blast resistance in Super Basmati is correlated with siderophore production $\left(\mathrm{r}_{\mathrm{pb}}=-0.59 ; \mathrm{P}=0.015\right)$, but not in Azucena $\left(\mathrm{r}_{\mathrm{pb}}=-0.3 ; \mathrm{P}=0.254\right)$, suggesting that this difference may account, at least in part, for the interaction identified in the ANOVA analysis. These relationships are illustrated in Fig. 1, which also shows that in general, more strains were able to reduce disease indices, and to a greater degree, in Azucena plants than in Super Basmati, irrespective of their ability to produce siderophores. There was no significant correlation between blast resistance and the production of antibiotics, chitinases or proteases by the bacteria. 
After initial scoring for disease, plants were kept for a further period of $40 \mathrm{~d}$ under normal growth conditions to see whether or not plants that initially showed disease symptoms recovered over time. Super Basmati plants inoculated with bacterial strains SPR7, SPR5, SPR4, WBPR4 and BPS10, which initially showed high disease incidence, were found to recover almost completely from the disease, whereas un-inoculated control plants were almost dead at that time. Similarly, in the case of rice cv Azucena, plants treated with bacterial strains WBPS1 and WBPS5 which were initially highly infected, showed $80 \%$ recovery after $40 \mathrm{~d}$ of challenge inoculation with blast fungus (Table 4).

\subsection{Bioantagonistic activity against M. grisea}

In the dual culture assays (Fig. 2) many of the bacterial strains significantly inhibited fungal growth over a period of $28 \mathrm{~d}$ (Table 3). Bacterial strains SPS2 and WBPR2 remained antagonistic at a level of $100 \%$ even after $40 \mathrm{~d}$ of assay. No physical contact was observed between any of the bacteria tested and M. grisea; moreover, an inhibitory halo was observed in the case of a few bacterial strains, suggesting the presence of fungistatic metabolites secreted by the bacteria. With bacterial strain SPS2, production of spores around the fungus causing complete fungal lysis was observed (Fig. 2). The bacterial strains were further investigated for production of volatile and diffusible antibiotics, which may provide them with bioantagonistic properties. Strains SPS2, Z2-7, WBPR2 and SPR7 produced both volatile and diffusible antibiotics, whilst BPS10 produced diffusible antibiotics only (Table 3). There appeared to be a strong association between siderophore production and in vitro antagonism (Fig. 3), which was confirmed by point biserial correlation analysis $\left(\mathrm{r}_{\mathrm{pb}}=0.88 ; \mathrm{P}\right.$ $<0.0001)$. There was also a significant, albeit weaker correlation, between antibiotic production and antagonism (Fig. 3; $\mathrm{r}_{\mathrm{pb}}=0.56 ; \mathrm{P}=0.023$ ). On the other hand, there was no correlation between antagonism and either chitinase $\left(\mathrm{r}_{\mathrm{pb}}=-0.31 ; \mathrm{P}=0.246\right)$ or protease $\left(\mathrm{r}_{\mathrm{pb}}=\right.$ 
$-0.13 ; \mathrm{P}=0.639)$ production. Since the majority of strains exhibited bioantagonistic activity against $M$. grisea, we plotted disease index against bioantagonism for Super Basmati and Azucena (Fig 4). There was a significant correlation between in vitro antagonism and the suppression of blast disease in Super Basmati, but not in Azucena. Hence, direct antagonistic activity cannot account for the disease suppressing activity of the PGPR strains in both rice cvs tested.

\subsection{Ephiphytic and rhizospheric colonization.}

To investigate colonisation of both roots and shoots of rice plants by our selected bacterial strains, we performed an experiment on plants grown in sterile sand, since we had no way of identifying the applied PGPR from amongst the microbial populations in the soil used in the first experiment. None of the bacterial strains were found to colonize plant leaf surfaces, suggesting that direct bioantagonistic activity is not a contributing factor to the reduction in blast disease incidence. Table 5 shows the levels of rhizospheric colonisation by the different strains at different times after soil inoculation. Bacterial populations varied considerably between strains, but colonisation by each strain (with the exception of WBPS5), was similar for both rice cvs. Bacterial population density for bacterial strains Z2-7, SPR7, SPR4, SPR5, SPS2 and WBPS1 remained high throughout the experiment in roots of both rice cvs, while that of the rest of the bacterial strains decreased substantially over time. We reasoned that persistence of the strains in the rhizosphere may account in part for the varied level of disease suppression between different PGPR treatments. Hence, disease indices were calculated following blast infection of PGPR-inoculated sand-grown plants as before. Although in general, the degree of disease protection afforded by the PGPR in sand was less than that observed for soil-grown plants, there was a similar effect of each strain on plants grown both in sand and soil. There were some exceptions to this in the case of Azucena, where strains 
SPR4, WBPS3 and WBPR2, showed substantial differences in the level of disease suppression in soil compared to sand. When we examined the relationship between colonisation and blast disease, we found a significant correlation between rhizosphere colonisation (at $25 \mathrm{~d}$ ) and disease index for Super Basmati (Pearson $\mathrm{r}=-0.62 ; \mathrm{P}=0.01$ ), but not for Azucena (Pearson $\mathrm{r}=0.057 ; \mathrm{P}=0.83$ ).

\subsection{Species identification by partial $16 S$ rRNA sequencing}

Bacterial isolates that were found to be most effective in controlling rice blast both in vitro and in vivo (SPS2, BPS10, BPS12, Z2-7, SPR4, SPR5 and SPR7), were identified using partial 16S rRNA gene sequencing. The sequences obtained were compared with those in public databanks, and on the basis of similarities with existing sequences, we were able to identify most isolates at least to the genus level, as shown in Table 1.

\section{Discussion}

A variety of bioantagonistic bacteria, including members of the genera Azospirillum, Azotobacter, Azoarcus, Pseudomonas, Bacillus and Enterobacter, are known to colonize the rhizosphere of most of the cereals, including maize, rice and wheat, and can be used as plant growth promoters and biocontrol agents (Reinhold-Hurek et al., 1993; Betelho et al., 1998; Naureen et al., 2005). The scope of this investigation was to isolate, characterize and select novel bacteria from the rice rhizosphere with potentially useful capabilities in terms of plant growth promotion and biological suppression of one of the most devastating rice pathogens, M. grisea. Rice disease suppression by biocontrol agents is governed by a multitude of factors. The influence of these factors varies with the type of biocontrol agent, plant cultivar and the nature of the pathogen targeted for control (Schroth and Hancock, 1981). There are different modes of action of biocontrol bacteria, such as inhibition of the pathogen by 
antimicrobial compounds (antibiosis), competition for iron through production of siderophores (Duffy and Défago, 1999), parasitism that may involve production of extracellular enzymes, (for example, chitinases and proteases that can lyse pathogen cell walls), and induction of plant resistance mechanisms (Whipps, 2001).

Here, we have identified new strains from a range of bacterial species with potential as biocontrol agents based on their ability to suppress the incidence of rice blast when they were applied to the roots. Many of the strains tested also show direct bioantagonistic activity against the rice blast fungus, $M$. grisea, which correlates with their ability to produce siderophores and antibiotics. Several of the strains also produce hydrolytic enzymes, which are also likely to play a role in direct antagonism (Ordentlick et al., 1988; Chernin and Chet, 2002; Kamensky et al., 2003). Epiphytic colonisation assays, however, suggest that under the conditions tested, there is likely to be no physical contact between the bioantagonistic bacteria and the pathogen on leaf surfaces. This suggests the induction of systemic resistance in rice by these bacterial strains. Induced systemic resistance (ISR) is a phenomenon whereby disease resistance against foliar pathogens is enhanced by rhizospheric bacteria or other antagonists which are spatially separated from the pathogen (van Loon et al., 1998). ISR has been recognised in a number of plant species, including radish (Raphanus sativus L.; Leeman et al., 1996b), Arabidopsis (van Wees et al., 1997), cucumber (Cucumis sativus L.; Chen et al., 1998), carnation (Dianthus caryophyllus L.; van Peer et al., 1991), and tomato (Solanum lycopersicum; Duijff et al., 1997). In rice, several bacterial strains have previously been identified that improve rice blast resistance, (Krishnamurthy and Gnanamanickam 1998, Someya et al. 2002, Yang et al. 2008, De Vleesschauwer et al. 2008). Our study substantially expands the collection, and it will now be of interest to investigate the molecular and cellular 
responses of rice plants to inoculation with our PGPR strains and their subsequent responses to blast infection to confirm the involvement of ISR in the suppression of blast disease.

Interestingly, siderophore production was correlated with blast resistance in soil-grown cv Super Basmati plants, but not in cv Azucena. No significant correlation was found between disease index and either antibiotic, chitinase or protease production. Iron availability and siderophore production have previously been identified as important determinants of ISR in several other systems, (Leeman et al., 1996a; Press et al., 1997; Audenaert et al., 2002; Meziane et al., 2005). Notably, it was found recently that the pseudobactin siderophore of $P$. fluorescens WCS374r is required for the establishment of ISR against rice blast disease (De Vleesschauwer et al. 2008). It will be of interest in the future to identify the siderophores produced by our new strains, and to characterise their effects on plants and microbes in more detail. However, it is clear that siderophores are not a primary determinant of the biocontrol potential of the PGPR tested, since there is no correlation between siderophore production and blast disease in Azucena. Indeed, the ability of individual strains to provide protection against blast disease varied considerably between the two cultivars, indicating a complex interaction between the PGPR and different rice cultivars. Inter- and intraspecific variation in plant ISR responses to PGPR is something which is commonly observed (van Loon, 1997).

The different levels of disease suppression in both rice cultivars grown in soil and sand might be due to the different colonization pattern and secretion of secondary metabolites by the rhizobacteria. Root colonization is a key factor contributing to the performance of bacterial inoculants - an introduced strain can only be effective in promoting plant growth and biocontrol activity if it is capable of associating with the roots of the plant (Goddard et al. 2001). In the present study, most of the bacterial strains were found to colonize well in the 
rhizosphere of both of the rice cultivars. In general bacterial strains Z2-7, SPR4, SPR5 SPR7, SPS2 and WBPS1 were found to persist better than the other strains, and this might be the reason for the better performance of these bacteria in controlling blast disease and enhancing plant health. The persistence of these strains could be attributed to siderophore production, since the soil iron concentration during the experiment was as low as $5 \mathrm{ug} \mathrm{g}^{-1}$ (data not shown). However, as indicated above, the situation is likely to be more complex than this, since whilst disease incidence, siderophore production and rhizosphere colonisation are all correlated in the case of Super Basmati, they are not for Azucena.

Some additional important capabilities of practical utility shown by some of these bacterial isolates were IAA production and P-solubilization, which suggested that these bacteria could be used as plant growth promoters (Paulina et al., 2001; Naureen et al., 2005). These properties might be responsible for the significant differences in seedling growth provided by the different bacterial strains, and suggests that these bacteria could be used as inoculants for rice to improve plant health and yield. Almost all of the bacterial strains were found to promote seedling growth (height and fresh weight) compared to control plants, but interestingly, bacterial strains that most improved seedling growth in Super Basmati were not as effective on Azucena plants, and vice versa. As for the promotion of disease resistance, this may be because bacterial association with roots of different plant cultivars is not only strain and species-specific, but also depends largely upon root exudates (Korhoenon et al., 1986; Naureen et al., 2005).

The use of natural or genetically modified micro-organisms as soil inocula for the development of sustainable cropping systems is a promising area for development. However, the successful release and application of PGPR in the field has been impeded partly because 
soil is a complex matrix that is difficult to manipulate with respect to environment and indigenous microbial populations. Soil type has been found to affect the ability of PGPR to colonize the rhizosphere or root-soil interface, and can account for the varying performance of PGPR in different systems (Suslow and Schroth, 1982; Horwarth et al., 1998). During our research, we also observed a difference in performance of various bacterial strains in promoting growth and controlling blast in plants grown in soil versus sand. Higher disease incidences were observed in plants grown in sand compared to soil, particularly for Super Basmati. However, the plants survived more than $46 \mathrm{~d}$, which was similar to the plants grown in soil. In the case of Azucena, some strains had very different impacts on disease, depending whether plants were grown in soil or sand, consistent with the fact that plant-inoculum interactions can be strongly influenced by soil type (Horwarth et al., 1998). This could be due to difference in soil texture, availability of nutrients and colonization pattern of the bacterial strains in the roots in the two soil types used (Goddard et al. 2001). Soil quality factors and carrier delivery systems should be important considerations in field trials to evaluating the performance of bacterial inoculants for agricultural applications. Strains SPS2, WBPS1 and Z2-7 reported here provided high levels of blast protection across all plant cultivars and growth substrates tested, and are therefore good candidates for such trials.

\section{Acknowledgements}

We are grateful to the Pakistan Higher Education Commission for the award of a $\mathrm{PhD}$ studentship to Zakira Naureen. We are also thankful to Ms. Sumera Yasmin (Plant Microbiology Division, NIBGE, Pakistan) for her help in physiological characterization of isolated bacteria, and for helpful comments on the manuscript. 


\section{References}

1. Audenaert, K., Pattery, T., Cornelis, P., Hofte, M., 2002. Induction of systemic resistance to Botrytis cinerea in tomato by Pseudomonas aeruginosa 7NSK2: Role of salicylic acid, pyochelin, and pyocyanin. Mol. Plant-Microbe Int. 15, 1147-1156.

2. Betelho, G.R., Guimaraes, V., De Bonis, M., Fonseca, M.E.F., Hagler, A.N., Hagler, L.C.M., 1998. Ecology of plant growth promoting strain of Pseudomonas fluorescens colonizing the maize endosphere in tropical soil. World J. Microbiol. Biotechnol. 14, 499504.

3. Chen, C., Bélanger, R.R., Benhamou, N., Paulitz, T.C., 1998. Induced systemic resistance (ISR) by Pseudomonas spp. impairs pre- and post-infection development of Pythium aphanidermatum on cucumber roots. Eur. J. Plant Pathol. 104, 877-886.

4. Chernin, L., Chet, I., 2002. Microbial enzymes in biocontrol of plant pathogens and pests. In: Burns, R.G., Dick, R.P. (Eds.), Enzymes in the environment: activity, ecology, and applications. Marcel Dekker, New York, pp. 171-225.

5. Compant, S., Duffy, B., Nowak, J., Clément, C., Barka E.A., 2005. Use of Plant GrowthPromoting Bacteria for Biocontrol of Plant Diseases: Principles, Mechanisms of Action, and Future Prospects. Appl. Environ. Microbiol. 71, 4951-4959.

6. De Vleesschauwer, D., Bakker, P.A.H.M., Djavaheri, M., Hofte, M 2008. Pseudomonas fluorescens WCS374r-induced systemic resistance in rice against Magnaporthe oryzae is based on pseudobactin-mediated priming for a salicylic acid-repressible multifaceted defense response. Plant Physiol. 148: 1996-2012.

7. Duffy, B. K., Défago, G., 1999. Environmental factors modulating antibiotic and siderophore biosynthesis by Pseudomonas fluorescens biocontrol strains. Appl. Environ. Microbiol. 65, 2429-2438. 
8. Duijff, B.J., Gianinazzi-Pearson, V., Lemanceau, P., 1997. Involvement of the outer membrane lipopolysaccharides in the endophytic colonization of tomato roots by biocontrol Pseudomonas fluorescens strain WCS417r. New Phytol. 135, 325-334.

9. Farmer, III, J.J., Arduino, M.J., Hickman-Brenner, F.W., 1992. The genera Aeromonas and Plesiomonas. In: Balows, A., Truper, H.G., Dworkin, M., Hardar, W., Schleifer, K.H. (Eds.), The Prokaryotes. Springer-Verlag, New York, pp. 3012-3045.

10. Goddard, V.J., Bailey, M.J., Darrah, P., Lilley, A.K., Thompson, I.P., 2001. Monitoring temporal and spatial variations in rhizosphere bacterial population diversity: A community approach for the improved selection of rhizosphere competent bacteria. Plant and Soil 232, 181-193.

11. Grimont, F., Grimont, P.A.D., 1992. The genus Enterobacter. In: Balows, A., Truper, H.G., Dworkin, M., Hardar, W., Schleifer, K.H. (Eds.), The Prokaryotes. SpringerVerlag, New York, pp. 2729-2815.

12. Hameed, S., Yasmin, S., Malik, K.A., Zafar, Y., Hafeez, F.Y., 2004. Rhizobium, Bradyrhizobium and Agrobacterium strains isolated from cultivated legumes. Biol. Fertil. Soils 39, 179-185.

13. Hardy, R.W.F., Burns, R.C., Holsten, R.D., 1973. Application of acetylene reduction assay for measurement of nitrogen fixation. Soil Biol. Biochem. 90, 245-254.

14. Hassan, U., Mirza, M.S., Menhaz, S., Rasul, G., Malik, K.A., 1998. Isolation and identification of diazotrophic bacteria from rice, wheat and kallar grass. In: Malik, K.A., Mirza, M.S., Ladha, J.K. (Eds.), Nitrogen fixation with non-legumes. Kluwer Academic Publishers, Dordrecht, pp. 197-205.

15. Horwath, W.R., Elliott, L.F., Lynch, J.M., 1998. Influence of soil quality on the function of inhibitory rhizobacteria. Lett. Appl. Microbiol. 26, 87-92. 
16. Kaiser, W.J., Harman, R.M., Weller, D.M., 1989. Biological control of seed rot and preemergence damping-off of chick pea with fluorescent Pseudomonads. Soil Biol. Biochem. 21, 269-273.

17. Kamensky, M., Ovadis, M., Chet, I., Chernin, L., 2003. Soil-borne strain IC14 of Serratia plymuthica with multiple mechanisms of antifungal activity provides biocontrol of Botrytis cinerea and Sclerotinia sclerotiorum diseases. Soil Biol. Biochem. 35, 323331.

18. Kazempour, M.N., 2004. Biological control of Rhizoctonia solani, the casual agent of rice sheath blight by antagonistc bacteria in greenhouse and field condition. Plant Pathol J. 3, $88-96$.

19. Korhonen, T.K., Lasilla, E. N., Laakso, T., Haahtela, K., 1986. Adhesion of nitrogen fixing enteric bacteria to roots of grasses and cereals. Plant and Soil 90, 59-69.

20. Krishnamurthy, K., Gnanamanickam, S.S., 1998 Induction of systemic resistance and salicylic acid accumulation in Oryza sativa, L. in the biological suppression of rice blast caused by treatments with Pseudomonas spp. World J. Microbiol. Biotechnol. 14, 935937.

21. Leeman, M., den Ouden, E.M., van Pelt, J.A., Dirkx, F.P.M., Steijl, H., Bakker, P.A.H.M., Schippers, B., 1996a. Iron availability affects induction of systemic resistance to Fusarium wilt of radish by Pseudomonas fluorescens. Phytopathol. 86, 149-155.

22. Leeman, M., den Ouden, F.M., van Pelt, J.A., Cornelissen, C., Matamala-Garros, A., Bakker, P.A.H.M., Schippers, B., 1996b. Suppression of Fusarium wilt of radish by coinoculation of fluorescent Pseudomonas spp. and root-colonizing fungi. Eur. J. Plant Pathol. 102, 21-31.

23. Lowry, H.O., Rosebrough, N.J., Farr, A.G., Randall, R.J., 1951. Protein measurement with Folin phenol reagent. J. Biol. Chem. 193, 265-275. 
24. Manandhar, H.K., Lyngs Jorgensen, H.J., Mathur, S.B., Smedegaard-Peterson, V., 1998. Suppression of rice blast by preinoculation with avirulent Pyricularia oryzae and the nonrice pathogen Bipolaris sorokiniana. Phytopathol. 88, 735-739.

25. Meziane, H., Van der Sluis, I., Van Loon, L.C., Hofte, M., Bakker, P.A.H.M., 2005. Determinants of Pseudomonas putida WCS358 involved in inducing systemic resistance in plants. Mol. Plant Pathol. 6, 177-185.

26. Miller, R.L., Higgins, V.J., 1970. Association of cyanide with infection of birdfoot trefoil by Stemphylium loti. Phytopathol. 60, 104-110.

27. Montealegre, J.R., Reyes, R., Pérez, L.M., Herrera, R., Silva, P., Besoain, X., 2003. Selection of bioantagonistic bacteria to be used in biological control of Rhizoctonia solani in tomato. Electronic J. Biotechnol. 6, 115-127.

28. Naureen, Z., Yasmin, S., Hameed, S., Malik, K.A., Hafeez, F.Y., 2005. Characterization and screening of plant growth promoting bacteria isolated from maize grown in Pakistani and Indonesian soil. J. Basic Microbiol. 45, 447-459.

29. Okon, Y., Albercht, S.L., Burris, R.H., 1977. Methods for growing Azospirillum lipoferum and for counting it in pure culture and in association with plants. Appl. Environ. Microbiol. 33, 85-88.

30. Ordentlich, A., Elad, Y., Chet, I., 1988. The role of chitinase of Serratia marcescens in biocontrol of Sclerotium rolfsii. Phytopathol. 78, 84-88.

31.Paulina, E.L., Bustillos-Cristales, R., Caballero-Mellado, J., 2001. Burkholderia, a genus rich in plant-associated nitrogen fixers with wide environmental and geographic distribution. Appl. Environ. Microbiol. 67, 2790-2798.

32. Pikovskaya, R.I., 1948. Mobilization of phosphorus in soil in connection with vital activity of some microbial species. Microbiologiya 17, 362-370. 
33. Press, C.M. Wilson, M., Tuzun, S., Kloepper J.W., 1997. Salicylic acid produced by Serratia marcescens $90-166$ is not the primary determinant of induced systemic resistance in cucumber or tobacco. Mol. Plant-Microbe Int. 10, 761-768.

34. Pumarino, A., 1995. Evaluación in vitro del control biológico de la Fusariosis del fréjol. Tesis (Memoria de Título Ingeniería Agraria). Santiago, Chile, Universidad de Chile, Facultad de Ciencias Agrarias y Forestales.

35. Raupach, G.S., Kloepper, J.W., 1998. Mixtures of plant growth-promoting rhizobacteria enhance biological control of multiple cucumber pathogens. Phytopathol. 88, 1158-1164.

36. Reinhold-Hurek, B., Hurek, T., Gillis, M., Hoste, B., Vancanneyt, M., Kersters, K., Peley, J., 1993. Azoarcus gen. nov., nitrogen-fixing proteobacteria associated with roots of Kallar grass (Leptochloa fusca (L.) Kunth) and description of two species., Azoarcus indigens sp. nov., and Azoarcus communis sp. nov. Int. J. Syst. Bacteriol. 43, 573-584.

37. Schroth, M.N., Hancock, J.G., 1981. Selected topics in biological control. Annu. Rev. Microbiol. 35, 453-476.

38. Schwyn, B., Neilands, J.B., 1987. Universal chemical assay for detection and determination of siderophores. Anal. Biochem. 160, 40-47.

39. Sharma, A., . Johri, B.N., 2002. Combat of iron deprivation through a plant growth promoting fluorescent Pseudomonas strain GRP3A in mung bean (Vigna ratiata L. Wilzeck). Microbiol. Res. 158, 77-81.

40. Someya, N., Nakajima, M., Hibi, T., Yamaguchi, I., Akutsu, K., 2002. Induced resistance to rice blast by antagonistic bacterium, Serratia marcescens strain B2. J. Gen. Plant Pathol. 68, 177-182.

41. Song, F., Goodman, R.M., 2001. Molecular biology of disease resistance in rice. Physiol. Mol. Plant Pathol. 59, 1-11. 
42. Sulsow, T.V., Schroth, M.N., 1982. Rhizobacteria of sugar beets: effects of seed application and root colonization on yield. Phytopathol. 72, 199-206.

43. van Loon, L.C., 1997. Induced resistance in plants and the role of pathogenesis-related proteins. Eur. J. Plant Pathol. 103, 753-765.

44. van Loon, L.C., Bakker, P.A.H.M., Pieterse, C.M.J., 1998. Systemic resistance induced by rhizosphere bacteria. Annu. Rev. Phytopathol. 36, 453-483.

45. van Peer, R., Niemann, G.J., Schippers, B., 1991. Induced resistance and phytoalexin accumulation in biological control of Fusarium wilt of carnation by Pseudomonas sp. WCS417r. Phytopathol. 81, 728-734.

46. van Wees, S.C.M., Pieterse, C.M.J., Trijssenaar, A., Van't Westende, Y., Hartog, F., van Loon, L.C., 1997. Differential induction of systemic resistance in Arabidopsis by biocontrol bacteria. Mol. Plant-Microbe Int. 10, 716-724.

47. van Wees, S.C.M., Van der Ent, S., Pieterse, C.M.J., 2008. Plant immune responses triggered by beneficial microbes. Curr. Opin. Plant Biol. 2008, 11, 1-6.

48. Vincent, J.M., 1970. A manual for the practical study of root nodule bacteria. Blackwell Scientific Publications, Oxford.

49. Whipps, J.M., 2001. Microbial interactions and biocontrol in the rhizosphere. J. Exp. Bot. $52,487-511$.

50. Yasmin, S., Baker, M.A.R., Malik, K.A., Hafeez, F.Y., 2004. Isolation, characterization and beneficial effects of rice-associated plant growth-promoting bacteria from Zanzibar soils. J. Basic Microbiol. 44, 241-252.

51. Yang, D.C., Oyaizu, Y., Oyaizu, H., Olsen, G.J., Woese, E.R., 1985. Mitochondrial origins. Proc. Natl. Acad. Sci. USA 82, 4443-4447. 
52. Yang, J.-H., Liu, H.-X., Zhu, G.-M., Pan, Y.-L., Xu, L.-P., Guo, J.-H., 2008. Diversity analysis of antagonists from rice-associated bacteria and their application in biocontrol of rice diseases. J. Appl. Microbiol. 104, 91-104.

53. Young, J.P.W., Downer, H.L., Eardly, D., 1991. Phylogeny of the phototrophic Rhizobium strain BTAi1 by polymerase chain reaction-based sequencing of a 16S rRNA gene segment. J. Bacteriol. 173, 2271-2277. 
Table 1. Morphological and physiological characterization and identification of bacterial isolates from rice grown in saline and non-saline soils.

\begin{tabular}{|c|c|c|c|c|c|c|c|}
\hline Strain $^{1}$ & $\begin{array}{c}\text { Gram } \\
\text { Reaction }\end{array}$ & Siderophore & $\mathrm{IAA}^{2}$ & $\mathrm{P}$ solubilization ${ }^{2}$ & $\begin{array}{l}\text { Chitinase } \\
\text { production }\end{array}$ & $\begin{array}{l}\text { Protease } \\
\text { production }\end{array}$ & $\begin{array}{c}\text { Identification by morphology } \\
\text { or } 16 \mathrm{~S} \text { rRNA sequencing } \\
\text { (Accession no.) }\end{array}$ \\
\hline Z2-7 (a) & + & + & + & - & + & - & Bacillus cereus (EF579778) \\
\hline SPR7 (b) & - & + & + & - & - & - & $\begin{array}{l}\text { Enterobacter sp. B41 } \\
\text { (EF579777) }\end{array}$ \\
\hline SPR4 (b) & - & + & + & - & - & - & $\begin{array}{l}\text { Serratia marcescens } \\
\text { (EF579774) }\end{array}$ \\
\hline SPR5 (b) & - & + & - & - & + & + & $\begin{array}{l}\text { Burkholderia xenovorans } \\
\text { (EF579772) }\end{array}$ \\
\hline SPS2 (c) & + & + & + & - & + & + & Bacillus subtilis (EF579773) \\
\hline WBPS1 (d) & - & + & - & + & - & + & ${ }^{3}$ Pseudomonas sp. \\
\hline WBPS2 (d) & - & - & - & - & - & - & ${ }^{3}$ Pseudomonas sp. \\
\hline WBPS3 (d) & - & - & - & - & + & - & ${ }^{3}$ Enterobacter sp. \\
\hline WBPS5 (d) & - & - & - & +++ & + & + & ${ }^{3}$ Pseudomonas sp. \\
\hline WBPS6 (d) & - & + & - & + & + & - & ${ }^{3}$ Pseudomonas sp. \\
\hline BPS10 (e) & - & + & + & + & - & - & $\begin{array}{l}\text { Aeromonas hydrophila } \\
\text { (EF579776) }\end{array}$ \\
\hline BPS12 (e) & - & + & - & + & + & - & Enterobacter sp. (EF579775) \\
\hline WBPR2 (f) & + & + & - & - & - & + & ${ }^{3}$ Bacillus sp. \\
\hline WBPR4 (f) & - & - & + & - & + & + & ${ }^{3}$ Enterobacter sp. \\
\hline WBPR5 (f) & - & - & - & - & + & + & ${ }^{3}$ Enterobacter sp. \\
\hline WBPR8 (f) & - & - & - & +++ & + & + & ${ }^{3}$ Pseudomonas sp. \\
\hline
\end{tabular}

${ }^{1}$ Origin of bacterial isolates: (a) Zanzibaar soil (Sumera et al. 2004), (b) rice roots from rice grown in saline soil, (c) saline soil, (d) rhizosphere of rice grown in saline soil, (e) non-saline soil, (f) rice roots from rice grown in non-saline soil.

${ }^{2}+$; present, -; absent; +++; enhanced activity.

3 tentative identification based on colony and cell morphology. 
Table 2. Effect of inoculation of different bacterial strains on seedling height, fresh weight (shoot) and no. of leaves of rice seedlings of the cultivars Super Basmati and Azucena

\begin{tabular}{ccccc}
\hline & \multicolumn{2}{c}{ Mean shoot length (mm) } & \multicolumn{2}{c}{ Avg. Fresh shoot weight (g) } \\
Strain & Super Basmati & Azucena & Super Basmati & Azucena \\
\hline Control & $214 \pm 2.11 \mathrm{e}$ & $215.8 \pm 3.18 \mathrm{e}$ & $6.4 \pm 2.01 \mathrm{~d}$ & $6.6 \pm 0.89 \mathrm{de}$ \\
Z2-7 & $272 \pm 1.52 \mathrm{~b}$ & $235 \pm 2.34 \mathrm{~d}$ & $8.2 \pm 1.89 \mathrm{c}$ & $7.4 \pm 0.921 \mathrm{~d}$ \\
SPR7 & $297 \pm 3.68 \mathrm{a}$ & $231 \pm 1.81 \mathrm{~d}$ & $9.04 \pm 1.58 \mathrm{a}$ & $7.2 \pm 0.74 \mathrm{~d}$ \\
SPR4 & $291 \pm 2.71 \mathrm{a}$ & $244 \pm 3.03 \mathrm{c}$ & $9.01 \pm 1.84 \mathrm{a}$ & $7.8 \pm 1.02 \mathrm{c}$ \\
SPR5 & $264 \pm 4.13 \mathrm{c}$ & $246 \pm 2.68 \mathrm{c}$ & $8.5 \pm 1.82 \mathrm{~b}$ & $8 \pm 1.68 \mathrm{c}$ \\
SPS2 & $274 \pm 1.61 \mathrm{~b}$ & $243 \pm 2.14 \mathrm{c}$ & $8.8 \pm 0.91 \mathrm{~b}$ & $7.8 \pm 0.54 \mathrm{c}$ \\
WBPS1 & $280 \pm 3.01 \mathrm{~b}$ & $259 \pm 1.28 \mathrm{~b}$ & $8.9 \pm 1.72 \mathrm{a}$ & $8.2 \pm 0.83 \mathrm{~b}$ \\
WBPS2 & $239 \pm 2.11 \mathrm{~d}$ & $271 \pm 5.04 \mathrm{a}$ & $7.1 \pm 2.21 \mathrm{~d}$ & $8.4 \pm 2.00 \mathrm{~b}$ \\
WBPS3 & $276 \pm 5.61 \mathrm{~b}$ & $227 \pm 4.26 \mathrm{~d}$ & $8.6 \pm 2.38 \mathrm{~b}$ & $6.8 \pm 1.12 \mathrm{~d}$ \\
WBPS5 & $281 \pm 1.36 \mathrm{~b}$ & $241 \pm 3.12 \mathrm{c}$ & $8.9 \pm 1.16 \mathrm{a}$ & $7.4 \pm 1.06 \mathrm{~d}$ \\
WBPS6 & $264 \pm 4.42 \mathrm{c}$ & $250 \pm 7.14 \mathrm{~b}$ & $8.4 \pm 1.76 \mathrm{c}$ & $8.1 \pm 2.46 \mathrm{~b}$ \\
BPS10 & $251 \pm 3.01 \mathrm{c}$ & $257 \pm 2.11 \mathrm{~b}$ & $8 \pm 1.52 \mathrm{c}$ & $8.1 \pm 0.68 \mathrm{~b}$ \\
BPS12 & $296 \pm 1.21 \mathrm{a}$ & $247 \pm 1.36 \mathrm{c}$ & $9.02 \pm 0.94 \mathrm{a}$ & $7.9 \pm 0.74 \mathrm{c}$ \\
WBPR2 & $280 \pm 3.12 \mathrm{~b}$ & $259 \pm 4.01 \mathrm{~b}$ & $8.8 \pm 1.01 \mathrm{~b}$ & $8.1 \pm 1.65 \mathrm{~b}$ \\
WBPR4 & $284 \pm 5.01 \mathrm{~b}$ & $254 \pm 1.93 \mathrm{~b}$ & $8.7 \pm 2.32 \mathrm{~b}$ & $7.9 \pm 0.69 \mathrm{c}$ \\
WBPR5 & $254 \pm 2.38 \mathrm{c}$ & $234 \pm 2.01 \mathrm{~d}$ & $7.9 \pm 1.82 \mathrm{c}$ & $6.9 \pm 0.74 \mathrm{~d}$ \\
WBPR8 & $247 \pm 5.24 \mathrm{c}$ & $271 \pm 3.38 \mathrm{a}$ & $7.1 \pm 1.22 \mathrm{~d}$ & $8.8 \pm 1.32 \mathrm{a}$ \\
\hline
\end{tabular}

Letters represent statistical groupings of the data defined by the Duncan multiple range test. 
Table 3. The effects of bacterial isolates on disease index in blast-inoculated rice cultivars Super Basmati and Azucena grown in soil and sand, and on fungal growth in vitro.

\section{Disease Index}

\begin{tabular}{|c|c|c|c|c|c|c|c|}
\hline Strain & $\underset{{\text { (soil })^{1}}^{\text {Super Basmati }}}{ }$ & $\begin{array}{l}\text { Super Basmati } \\
\quad(\text { sand })^{1}\end{array}$ & $\begin{array}{c}\text { Azucena } \\
{\text { (soil })^{1}}^{-1}\end{array}$ & $\begin{array}{c}\text { Azucena } \\
\text { (sand) })^{1}\end{array}$ & Dual culture $^{2}$ & $\begin{array}{c}\text { Diffusible } \\
\text { antibiotics }\end{array}$ & $\begin{array}{c}\text { Volatile } \\
\text { antibiotics }^{2}\end{array}$ \\
\hline Control & $2 \pm 0.05$ & $2 \pm 0.01$ & $2 \pm 0.07$ & $2 \pm 0.02$ & 0 & 0 & 0 \\
\hline $\mathbf{Z 2 - 7}$ & $0.6 \pm 0.04$ & $0.91 \pm 0.11$ & $0.55 \pm 0.04$ & $1.16 \pm 0.03$ & $95 \pm 0.57$ & $84 \pm 1.22$ & $68 \pm 3.24$ \\
\hline SPR7 & $1.26 \pm 0.02$ & $1.48 \pm 0.01$ & $1.4 \pm 0.06$ & $1.85 \pm 0.05$ & $90 \pm 0.34$ & $61 \pm 0.62$ & $42 \pm 0.74$ \\
\hline SPR4 & $1.2 \pm 0.01$ & $1.92 \pm 0.03$ & $0.25 \pm 0.03$ & $1.37 \pm 0.06$ & $95 \pm 0.26$ & 0 & 0 \\
\hline SPR5 & $1.05 \pm 0.07$ & $1.88 \pm 0.02$ & $0.35 \pm 0.02$ & $0.52 \pm 0.02$ & $98 \pm 0.11$ & 0 & 0 \\
\hline SPS2 & $0.65 \pm 0.02$ & $0.67 \pm 0.01$ & $0.4 \pm 0.02$ & $0.45 \pm 0.01$ & $100 \pm 0.02$ & $98 \pm 2.24$ & $100 \pm 0.00$ \\
\hline WBPS1 & $0.35 \pm 0.03$ & $0.88 \pm 0.03$ & $0.9 \pm 0.03$ & $0.73 \pm 0.11$ & $80 \pm 0.32$ & 0 & 0 \\
\hline WBPS2 & $0.8 \pm 0.02$ & $1.62 \pm 0.12$ & $0.6 \pm 0.03$ & $1.13 \pm 0.01$ & $10 \pm 0.12$ & 0 & 0 \\
\hline WBPS3 & $1.75 \pm 0.05$ & $2 \pm 0.04$ & $1.3 \pm 0.04$ & $0.35 \pm 0.03$ & $23 \pm 1.03$ & 0 & 0 \\
\hline WBPS5 & $2.01 \pm 0.02$ & $2 \pm 0.21$ & $0.7 \pm 0.03$ & $0.71 \pm 0.02$ & $49 \pm 2.34$ & 0 & 0 \\
\hline WBPS6 & $1.25 \pm 0.05$ & $2 \pm 0.02$ & $0.85 \pm 0.05$ & $1.06 \pm 0.06$ & $30 \pm 1.14$ & 0 & 0 \\
\hline BPS10 & $1.99 \pm 0.02$ & $2 \pm 0.06$ & $0.15 \pm 0.09$ & $0.25 \pm 0.02$ & $80 \pm 2.04$ & $46 \pm 0.34$ & 0 \\
\hline BPS12 & $0.5 \pm 0.02$ & $1.84 \pm 0.07$ & $0.55 \pm 0.07$ & $1.53 \pm 0.15$ & $100 \pm 0.00$ & 0 & 0 \\
\hline WBPR2 & $1.2 \pm 0.06$ & $1.9 \pm 0.13$ & $1.23 \pm 0.21$ & $0.11 \pm 0.13$ & $100 \pm 0.00$ & 0 & 0 \\
\hline WBPR4 & $2.01 \pm 0.04$ & $2 \pm 0.17$ & $0.25 \pm 0.02$ & $0.14 \pm 0.02$ & $10 \pm 0.28$ & 0 & 0 \\
\hline WBPR5 & $2.03 \pm 0.15$ & $2 \pm 0.23$ & $0.95 \pm 0.02$ & $1.3 \pm 0.01$ & $5 \pm 0.06$ & 0 & 0 \\
\hline WBPR8 & $1.55 \pm 0.06$ & $1.91 \pm 0.01$ & $2.05 \pm 0.14$ & $1.3 \pm 0.01$ & $2 \pm 0.28$ & 0 & 0 \\
\hline
\end{tabular}

1. Disease Index; mean and standard deviation.

2. Mean $\%$ and standard deviation.

\section{M. grisea growth inhibition}

Diffusible Volatile 
Table 4. Mean percent survival of rice plants of cvs Super Basmati and Azucena grown in soil and sand, $46 \mathrm{~d}$ after challenge inoculation with $M$. grisea.

\section{Super Basmati Azucena}

\begin{tabular}{|c|c|c|c|c|}
\hline Strain & Soil & Sand & Soil & Sand \\
\hline Control & $0 \pm 0.00$ & $0 \pm 0.00$ & $0 \pm 0.00$ & $0 \pm 0.00$ \\
\hline Z2-7 & $100 \pm 0.04$ & $100 \pm 0.00$ & $80 \pm 0.13$ & $71 \pm 0.03$ \\
\hline SPR7 & $100 \pm 0.00$ & $100 \pm 0.00$ & $40 \pm 2.14$ & $46 \pm 1.00$ \\
\hline SPR4 & $80 \pm 0.01$ & $75 \pm 0.00$ & $100 \pm 0.03$ & $80 \pm 0.02$ \\
\hline SPR5 & $100 \pm 0.12$ & $100 \pm 0.32$ & $80 \pm 0.00$ & $70 \pm 0.40$ \\
\hline SPS2 & $100 \pm 0.02$ & $100 \pm 0.21$ & $100 \pm 0.14$ & $95 \pm 0.00$ \\
\hline WBPS1 & $100 \pm 1.00$ & $100 \pm 0.3$ & $80 \pm 1.30$ & $85 \pm 0.04$ \\
\hline WBPS2 & $72 \pm 0.03$ & $79 \pm 0.00$ & $65 \pm 0.04$ & $80 \pm 1.53$ \\
\hline WBPS3 & $0 \pm 1.33$ & $4 \pm 2.13$ & $0 \pm 0.00$ & $2 \pm 0.00$ \\
\hline WBPS5 & $10 \pm 2.01$ & $15 \pm 1.00$ & $80 \pm 0.41$ & $76 \pm 3.30$ \\
\hline WBPS6 & $32 \pm 2.12$ & $31 \pm 3.30$ & $80 \pm 0.00$ & $82 \pm 0.23$ \\
\hline BPS10 & $80 \pm 0.12$ & $78 \pm 0.20$ & $100 \pm 0.21$ & $100 \pm 0.34$ \\
\hline BPS12 & $60 \pm 0.43$ & $58 \pm 0.32$ & $60 \pm 0.31$ & $60 \pm 0.02$ \\
\hline WBPR2 & $21 \pm 3.01$ & $21 \pm 2.05$ & $36 \pm 4.03$ & $37 \pm 0.52$ \\
\hline WBPR4 & $80 \pm 0.00$ & $80 \pm 0.00$ & $100 \pm 0.00$ & $100 \pm 0.00$ \\
\hline WBPR5 & $8 \pm 4.00$ & $8 \pm 4.50$ & $40 \pm 0.00$ & $31 \pm 0.00$ \\
\hline WBPR8 & $10 \pm 4.13$ & $10 \pm 2.54$ & $25 \pm 0.44$ & $22 \pm 0.05$ \\
\hline
\end{tabular}


Table 5. Rhizospheric colonization $\left(\mathrm{cfu} \mathrm{ml}^{-1}\right)$ of Super Basmati plants by various bacterial isolates at different time intervals.

\begin{tabular}{|c|c|c|c|c|c|c|}
\hline \multirow[t]{2}{*}{ Strain } & \multicolumn{3}{|c|}{ Super Basmati } & \multicolumn{3}{|c|}{ Azucena } \\
\hline & 7 days & 25 days & 45 days & 7 days & 25 days & 45 days \\
\hline $\mathrm{Z} 2-7$ & $4.5 \times 10^{9}$ & $5 \times 10^{9}$ & $5 \times 10^{8}$ & $4.5 \times 10^{9}$ & $4.5 \times 10^{8}$ & $4.1 \times 10^{8}$ \\
\hline SPR7 & $4.6 \times 10^{9}$ & $5.0 \times 10^{9}$ & $5.0 \times 10^{8}$ & $4.6 \times 10^{9}$ & $4.1 \times 10^{9}$ & $3.5 \times 10^{8}$ \\
\hline SPR4 & $4.5 \times 10^{9}$ & $5.0 \times 10^{9}$ & $5.0 \times 10^{8}$ & $4.5 \times 10^{9}$ & $5.0 \times 10^{9}$ & $5.0 \times 10^{9}$ \\
\hline SPR5 & $4.5 \times 10^{9}$ & $5.0 \times 10^{9}$ & $5.0 \times 10^{8}$ & $4.5 \times 10^{9}$ & $5.0 \times 10^{8}$ & $4.5 \times 10^{7}$ \\
\hline SPS2 & $4.5 \times 10^{9}$ & $5.0 \times 10^{9}$ & $5.0 \times 10^{8}$ & $4.5 \times 10^{9}$ & $5.0 \times 10^{9}$ & $5.0 \times 10^{9}$ \\
\hline WBPS1 & $4.5 \times 10^{9}$ & $5.0 \times 10^{9}$ & $5.0 \times 10^{8}$ & $4.5 \times 10^{9}$ & $4.4 \times 10^{9}$ & $4.5 \times 10^{8}$ \\
\hline WBPS2 & $4.2 \times 10^{9}$ & $4.0 \times 10^{8}$ & $4.1 \times 10^{7}$ & $4.2 \times 10^{9}$ & $4.1 \times 10^{6}$ & $3.1 \times 10^{6}$ \\
\hline WBPS3 & $4.3 \times 10^{9}$ & $2.0 \times 10^{3}$ & $2.0 \times 10^{3}$ & $4.3 \times 10^{9}$ & $2.0 \times 10^{3}$ & $1.0 \times 10^{2}$ \\
\hline WBPS5 & $4.1 \times 10^{9}$ & $3.0 \times 10^{4}$ & $2.0 \times 10^{2}$ & $4.1 \times 10^{9}$ & $3.8 \times 10^{7}$ & $3.2 \times 10^{6}$ \\
\hline WBPS6 & $4.5 \times 10^{9}$ & $2.6 \times 10^{5}$ & $2.1 \times 10^{5}$ & $4.5 \times 10^{9}$ & $3.6 \times 10^{7}$ & $3.9 \times 10^{6}$ \\
\hline BPS10 & $4.3 \times 10^{9}$ & $4.3 \times 10^{9}$ & $5.0 \times 10^{6}$ & $4.3 \times 10^{9}$ & $4.3 \times 10^{9}$ & $4.5 \times 10^{7}$ \\
\hline BPS12 & $4.5 \times 10^{9}$ & $4.0 \times 10^{8}$ & $3.0 \times 10^{5}$ & $4.5 \times 10^{9}$ & $4.1 \times 10^{8}$ & $2.3 \times 10^{5}$ \\
\hline WBPR2 & $4.5 \times 10^{9}$ & $3.0 \times 10^{5}$ & $3.0 \times 10^{5}$ & $4.5 \times 10^{9}$ & $4.1 \times 10^{5}$ & $3.3 \times 10^{5}$ \\
\hline WBPR4 & $4.1 \times 10^{9}$ & $4.0 \times 10^{8}$ & $4.1 \times 10^{7}$ & $4.1 \times 10^{9}$ & $4.5 \times 10^{8}$ & $3.9 \times 10^{6}$ \\
\hline WBPR5 & $4.3 \times 10^{9}$ & $4.0 \times 10^{6}$ & $2.0 \times 10^{4}$ & $4.3 \times 10^{9}$ & $4.1 \times 10^{6}$ & $4.2 \times 10^{4}$ \\
\hline WBPR8 & $4.5 \times 10^{9}$ & $3.0 \times 10^{5}$ & $2.0 \times 10^{5}$ & $4.5 \times 10^{9}$ & $3.2 \times 10^{5}$ & $3.2 \times 10^{5}$ \\
\hline
\end{tabular}


Figures

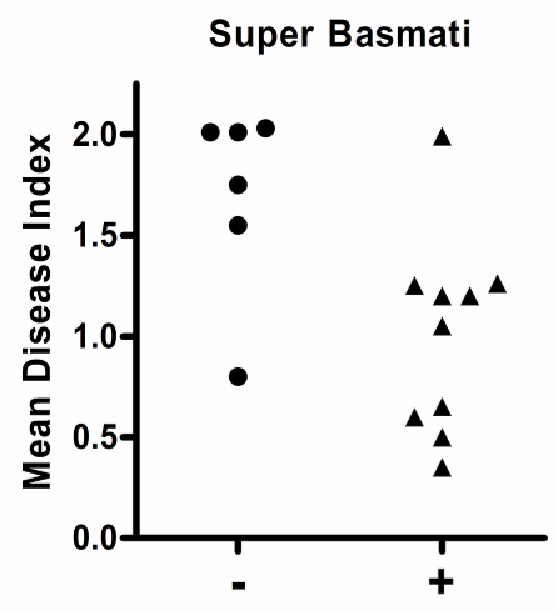

Siderophore

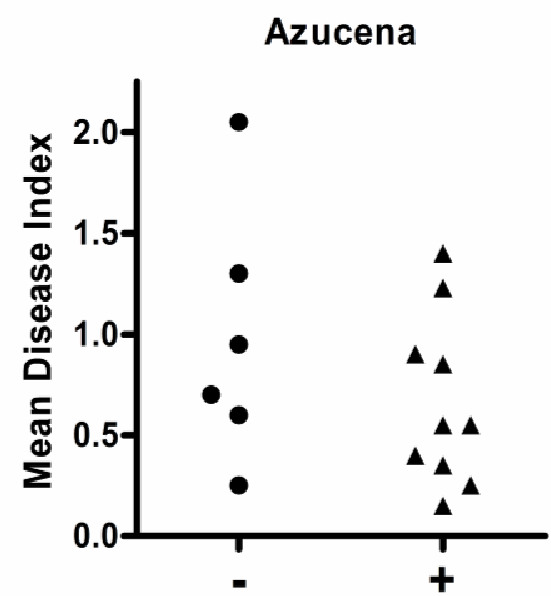

Siderophore

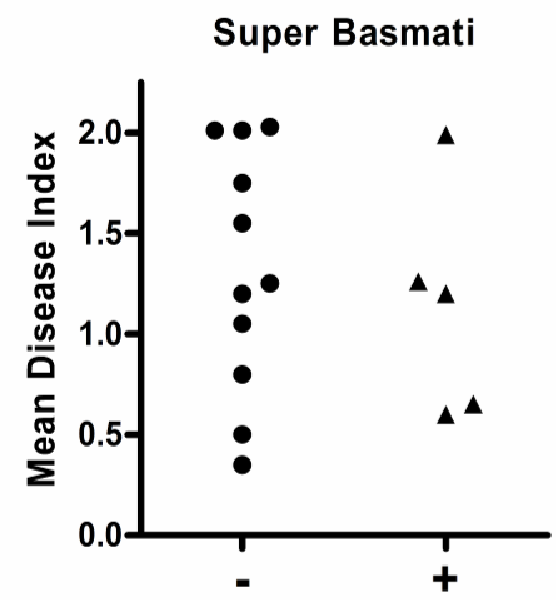

Antibiotics

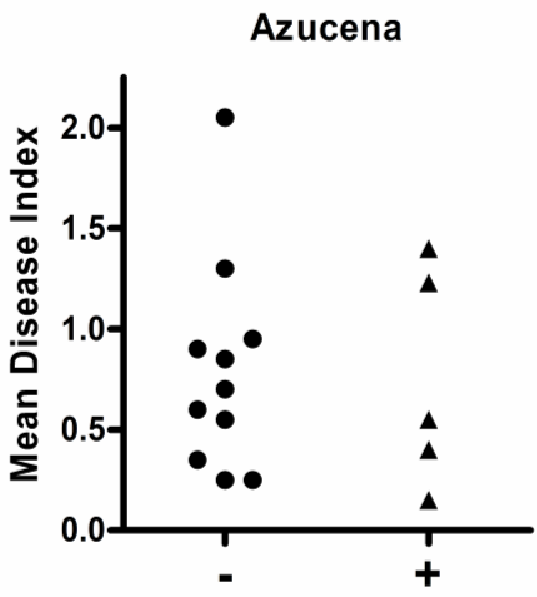

Antibiotics

Figure 1. Relationship between the production of siderophores and antibiotics by rhizobacteria and disease index in blast-inoculated cvs Super Basmati and Azucena rice grown in soil. 


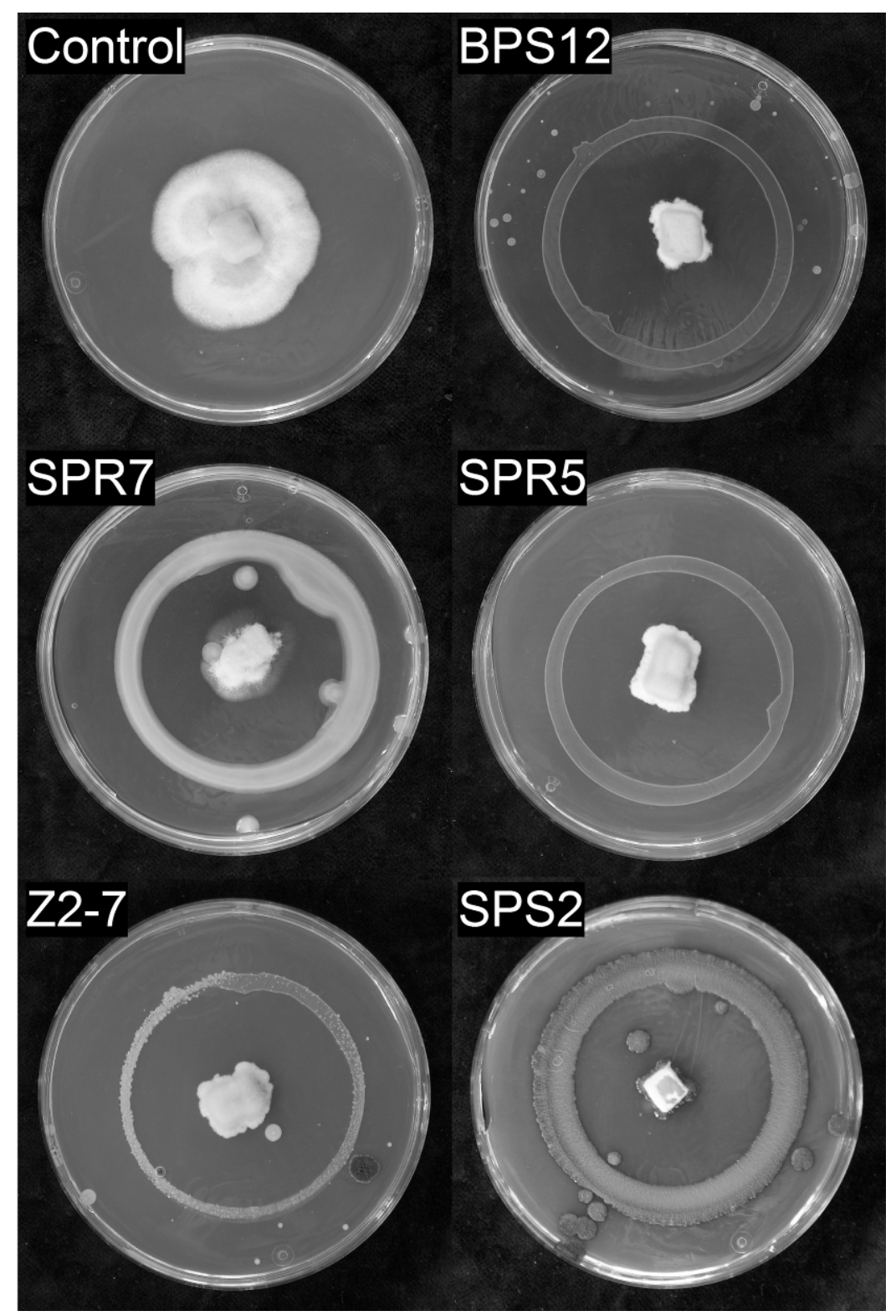

Figure 2. Dual culture bioantagonistic assay for inhibition of blast fungus by selected bacterial strains. Fungal cultures are in the centre of the plate; bacterial inoculants around the perimeter. 


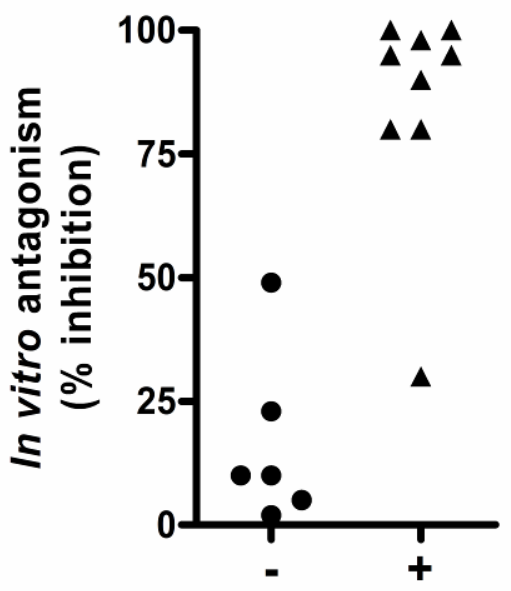

Siderophore

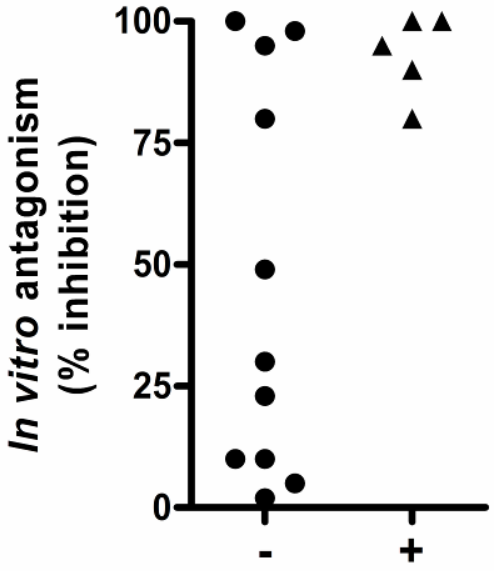

Antibiotics

Figure 3. Relationship between the production of siderophores and antibiotics by rhizobacteria and in vitro antagonism of growth of M. grisea. 
Super Basmati

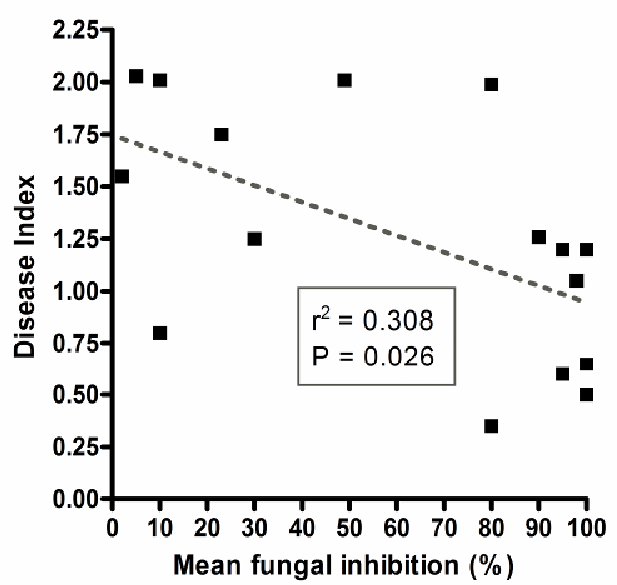

Azucena

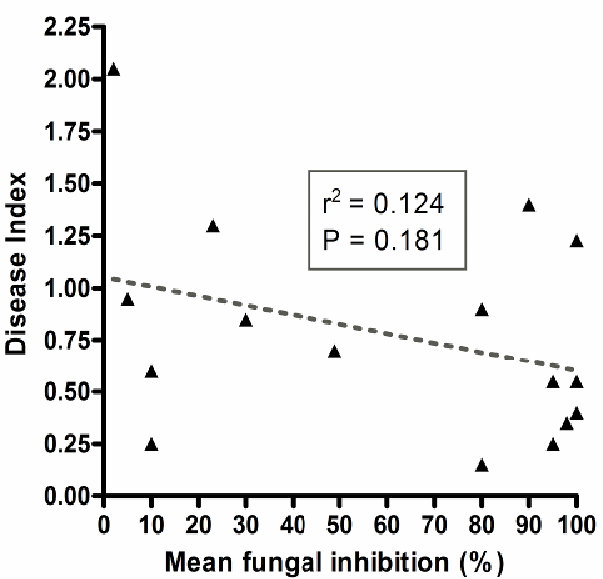

Figure 4. Relationship between the ability of PGPR to suppress blast disease in cvs Super Basmati and Azucena rice and their in vitro antagonistic activity against the blast fungus, $M$. grisea. Linear regression lines are shown as dashed lines, with $\mathrm{r}^{2}$ values and the probability for the significance of the correlation shown in the inset boxes. 